\title{
Cytotoxic effects of nivalenol on HL60 cells
}

\author{
Hitoshi NAGASHIMA, Hiroyuki NAKAGAWA and Keiko IwASHITA \\ National Agriculture and Food Research Organization, National Food Research Institute \\ (2-1-12 Kannondai, Tsukuba, Ibaraki 305-8642, Japan)
}

\begin{abstract}
Summary
To elucidate the underlying mechanism of nivalenol toxicity, we treated human promyelocytic leukemia HL60 cells with nivalenol for $24 \mathrm{~h}$ and investigated the toxin's effects on cell viability and interleukin (IL)-8 secretion. Whereas exposure to $1 \mu \mathrm{g} / \mathrm{ml}$ nivalenol led to slight morphologic damage, that after treatment with $3 \mathrm{or} 10 \mu \mathrm{g} / \mathrm{ml}$ nivalenol was pronounced. In 5-bromo-2-deoxyuridine (BrdU) incorporation assays of the rate of cell proliferation, the mean $50 \%$ inhibitory concentration $\left(\mathrm{IC}_{50}\right)$ of nivalenol was $0.16 \mu \mathrm{g} / \mathrm{ml}$. The effect of nivalenol on mitochondrial succinic dehydrogenase activity was examined using the water-soluble tetrazolium- 8 assay, in which the mean $\mathrm{IC}_{50}$ was $0.40 \mu \mathrm{g} / \mathrm{ml}$. The activity of lactate dehydrogenase $(\mathrm{LDH})$ released from the cytoplasm was very low, even at $10 \mu \mathrm{g} / \mathrm{ml}$ nivalenol, indicating that although treated cells had extensive morphologic damage, they did not burst. We used BrdU incorporation (the most sensitive indicator of cell viability) to assess the effect of 1,2bis(2-aminophenoxy)ethane-N,N,N',N'-tetraacetic acid tetraacetoxymethyl ester (BAPTA-AM), which chelates intracellular calcium ion, on nivalenol toxicity. BrdU incorporation after concomitant treatment with nivalenol and BAPTA-AM was higher than that after treatment with nivalenol alone, indicating that the cytotoxicity of nivalenol is dependent in part on intracellular calcium ion. Further, the media of nivalenol-treated cells contained substantial amounts of IL-8, suggesting that this cytokine contributes to the nivalenol-caused pathologic phenomena.
\end{abstract}

Key words : nivalenol, interleukin-8, BAPTA-AM, HL60 cells

(Received: February 23, 2006, Accepted: May 11, 2006)

\section{Introduction}

Nivalenol (Fig. 1), a trichothecene mycotoxin, is a secondary metabolite produced by various Fusarium fungi. In Japan, nivalenol contamination of wheat and barley is as prevalent as that of deoxynivalenol, another trichothecene mycotoxin ${ }^{1,2)}$. Although the acute toxicity of nivalenol is thought to be equivalent to or more potent than that of deoxynivalenol, the paucity of reports suggests that nivalenol has garnered far less interest than deoxynivalenol. In light of these circumstances, the study of nivalenol toxicity deserves more attention in Japan. Trichothecene mycotoxins are extremely toxic to rapidly dividing cells including leukocytes ${ }^{3)}$, and one of the leading symptoms of trichothecene toxicosis is the leukopenia known as alimentary toxic aleukia (ATA) ${ }^{4)}$. Therefore, to elucidate the mechanism underlying the toxicity of nivalenol, we investigated its 


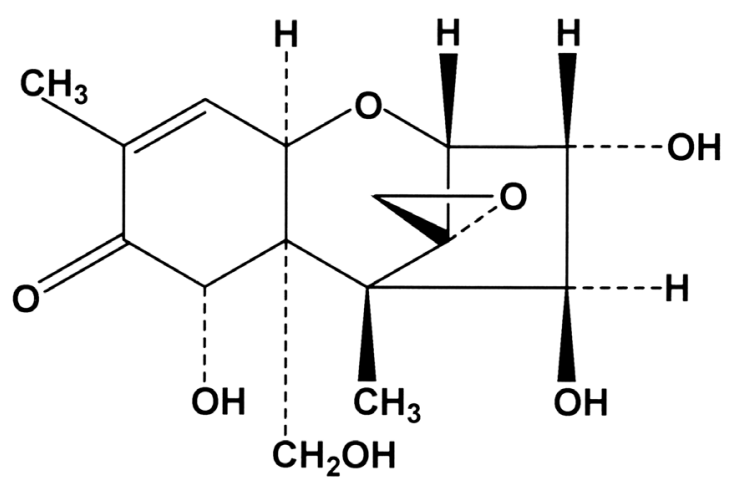

Fig. 1. Chemical structure of nivalenol.

cytotoxicity to the human promyelocyte-derived cell line HL60.

\section{Materials and methods}

Chemicals and cells Nivalenol was purchased from Sigma-Aldrich Corporation (St. Louis, MO, USA). Lactate Dehydrogenase CII-Testwako and 1,2-bis(2-aminophenoxy) ethane-N,N,N',N'-tetraacetic acid tetraacetoxymethyl ester (BAPTA-AM) were purchased from Wako Pure Chemical Industries, Ltd. (Osaka, Japan). Nivalenol and BAPTA-AM were dissolved in dimethyl sulfoxide. Cell proliferation ELISA, BrdU (Colorimetric) and Cell Counting Kit-8 (water-soluble tetrazolium [WST] -8 assay) were purchased from Roche Diagnostics GmbH (Penzberg, Germany) and Dojindo Laboratories (Kumamoto, Japan), respectively. The human promyelocytic leukemia cell line HL60 was purchased from the RIKEN Cell Bank (Tsukuba, Japan) and cultured in RPMI 1640 medium containing $10 \%$ fetal calf serum.

Morphologic study Approximately $4 \times 10^{5}$ cells in $2 \mathrm{ml}$ of medium with nivalenol were cultured in each well of a 6 -well culture plate for $24 \mathrm{~h}$, then examined under a microscope.

Assessment of cell viability The methods used to measure 5-bromo-2-deoxyuridine (BrdU) incorporation during DNA synthesis and mitochondrial succinic dehydrogenase activity (WST-8 assay) were described previously). Approximately $5 \times 10^{3}$ cells (BrdU assay) or $2 \times 10^{4}$ cells (WST8 assay) in $100 \mu 1$ medium with chemicals were placed in each well of a 96-well microtiter plate and incubated for $24 \mathrm{~h}$.

Cytoplasmic lactate dehydrogenase $(\mathrm{LDH})$ is leaked to the culture medium after cell death and subsequent rupture of the cell membrane. LDH activity in the culture supernatant was measured as follows $^{6}$. Approximately $1 \times 10^{5}$ cells in $0.5 \mathrm{ml}$ medium containing either nivalenol or $0.1 \%$ Tween 20 were cultured for $24 \mathrm{~h}$ in each well of a 24-well culture plate. Media then were collected and centrifuged at $5,000 \times \mathrm{g}$ for $5 \mathrm{~min}$ to remove cells and debris, and supernatants were subjected to LDH assay. A 30- $\mu 1$ aliquot of supernatant was added to $200 \mu 1$ Lactate Dehydrogenase CII-Testwako color solution. After $30 \mathrm{~min}$ incubation at $37{ }^{\circ} \mathrm{C}, 2 \mathrm{ml} 0.1 \mathrm{~N}$ hydrochloric acid was added to stop the reaction, and then optical densities at $560 \mathrm{~nm}$ were read. We assumed the activities of the Tween 20treated controls to be $100 \%$, and the activities of samples were expressed as relative percentages. 
Determination of interleukin (IL) -8 levels Approximately $1 \times 10^{5}$ cells in $0.5 \mathrm{ml}$ medium containing nivalenol were cultured for $24 \mathrm{~h}$ in each well of a 24 -well culture plate. Media were collected and centrifuged at 5,000 $\times \mathrm{g}$ for $5 \mathrm{~min}$ to remove cells and debris, and the levels of IL- 8 in the culture supernatants were quantified using the Quantikine Human IL-8 Immunoassay kit (R\&D Systems, Inc., Minneapolis, MN, USA) according to the manufacturer's recommended procedure.

Statistics Data are expressed as mean \pm standard deviation. Logarithmically transformed data were statistically analyzed. Differences between groups were analyzed using Tukey's test or Dunnett's test. A $P$ value of $<0.05$ was considered to be significant.

\section{Results and Discussion}

At $1 \mu \mathrm{g} / \mathrm{ml}(3.2 \mu \mathrm{M})$ nivalenol (Fig. 2B), slight morphologic damage was apparent, and most of the cells looked sound. In contrast, cells treated with 3 or $10 \mu \mathrm{g} / \mathrm{ml}$ nivalenol clearly were damaged (Fig. 2C, D), and more than half of the cells were dead under these experimental conditions. Using morphologic damage as a criterion, the $50 \%$ cytotoxic concentration $\left(\mathrm{CC}_{50}\right)$ of nivalenol is between 1 and $3 \mu \mathrm{g} / \mathrm{ml}$.

It has been reported that nivalenol inhibits cell proliferation ${ }^{7-10)}$, therefore, we measured $\mathrm{BrdU}$ incorporation to determine the rate of cell proliferation. We repeated the experiment 4 times, and the mean value of $50 \%$ inhibitory concentration ( $\mathrm{IC}_{50}$ ) of nivalenol was $0.16 \mu \mathrm{g} / \mathrm{ml}$ (Table 1 ). Our result is consistent with that of Minervini et al. ${ }^{8)}$, who reported a value of $0.6 \mu \mathrm{M}(0.187 \mu \mathrm{g} / \mathrm{ml})$. In contrast, $\mathrm{IC}_{50 \mathrm{~S}}$ reported by Thuvander et $\mathrm{al}^{9}{ }^{9)}(0.24-0.36 \mu \mathrm{M} ; 0.075-0.112 \mu \mathrm{g} / \mathrm{ml})$ and Johannisson et al. ${ }^{10)}$ (approximately $0.2 \mu \mathrm{M} ; 0.062 \mu \mathrm{g} / \mathrm{ml}$ ) were lower than ours. Both of these other groups tested human lymphocytes, which might be more vulnerable to nivalenol than other cell types would be.

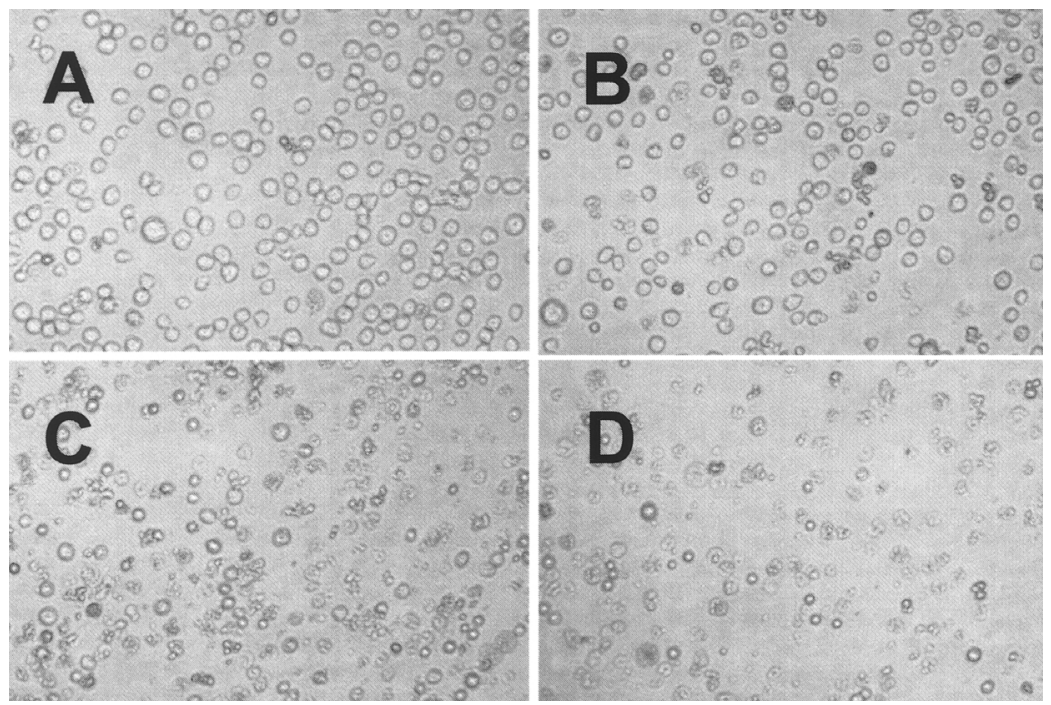

Fig. 2. Nivalenol-caused morphologic change in HL60 cells.

(A) Vehicle control. Cells treated with (B) $1 \mu \mathrm{g} / \mathrm{ml}$, (C) $3 \mu \mathrm{g} / \mathrm{ml}$, or (D) $10 \mu \mathrm{g} / \mathrm{ml}$ nivalenol for $24 \mathrm{~h}$. (Magnification, $\times$ 400) 
Triplicate WST- 8 assays indicated that the mean $\mathrm{IC}_{50}$ of nivalenol was $0.40 \mu \mathrm{g} / \mathrm{ml}$ (Table 1 ). The effect of nivalenol on mitochondrial succinic dehydrogenase activity has been examined using MTT $\operatorname{assay}^{8,11,12)}$, which determines enzyme activities by the same principle as WST-8 assay, but the results of these previous studies vary. Minervini et al. reported that the $\mathrm{IC}_{50}$ of nivalenol in $\mathrm{K} 562$ cells was $0.5 \mu \mathrm{M}(0.16 \mu \mathrm{g} / \mathrm{ml})^{8}$. However, Yang et al. did not observe any effect of nivalenol on RAW 364.7 and U937 cells at concentrations of $10 \mu \mathrm{g} / \mathrm{ml}$ or lower ${ }^{11)}$, whereas according to Sugita-Konishi and Pestka, the $\mathrm{IC}_{50}$ of nivalenol in U937 cells was approximately $1 \mu \mathrm{g} / \mathrm{ml}^{12)}$. It is likely that these discrepancies are due to differences in experimental conditions, including cell type.

We measured supernatant LDH activity 3 times. At $10 \mu \mathrm{g} / \mathrm{ml}$ nivalenol or lower, supernatant LDH activity was less than $50 \%$ that in Tween 20-treated samples $\left(\mathrm{CC}_{50}\right.$; Table 1$)$ under our experimental conditions. Although HL60 cells treated with $10 \mu \mathrm{g} / \mathrm{ml}$ nivalenol showed profound morphologic change (Fig. 2D), presumably the cells did not burst. Because nivalenol reportedly induces apoptosis in HL60 cells ${ }^{13)}$, we considered that the marked nivalenol-caused morphologic change was due to apoptosis. Minervini et al. used trypan blue exclusion test, another test that is based on breakage of cell membrane ${ }^{8)}$, to monitor cell viability. They found that $80 \%$ of K562 cells were viable even at $25.0 \mu \mathrm{g} / \mathrm{ml}$ nivalenol ${ }^{8)}$ - a finding that is consistent with our result regarding cytoplasmic $\mathrm{LDH}$ activity.

Because it is reported that the intracellular calcium ion chelator BAPTA-AM inhibited trichothecene mycotoxin T-2 toxin-induced apoptosis in HL60 cells ${ }^{14)}$, we investigated the chelator's effect on nivalenol toxicity in these cells. We chose BrdU incorporation for this purpose, because in our hands, this test was the most sensitive measure of cell viability (Fig. 2, Table 1). Treatment with BAPTA-AM alone slightly hindered cell proliferation (78.5\% that of vehicle-treated control samples; Table 2). Cell proliferation after concomitant treatment with nivalenol and BAPTA-AM (17.1 \%) was greater than that after treatment with nivalenol alone $(10.3 \%)$, and the difference between these

Table 1. Cytotoxicity of nivalenol to HL60 cells

\begin{tabular}{|c|c|c|c|c|}
\hline & $\operatorname{BrdU}\left(\mathrm{IC}_{50}\right)$ & WST-8 (IC 50$)$ & $\mathrm{LDH}\left(\mathrm{CC}_{50}\right)$ & $(\mu \mathrm{g} / \mathrm{ml})$ \\
\hline Nivalenol & $0.16 \pm 0.03$ & $0.40 \pm 0.03$ & $>10$ & \\
\hline
\end{tabular}

Table 2. Effect of BAPTA-AM on nivalenol-caused inhibition of HL60 cell proliferation

\begin{tabular}{ccc}
\hline & \multicolumn{2}{c}{ Nivalenol $(0.3 \mu \mathrm{g} / \mathrm{ml})$} \\
\cline { 2 - 3 } & \multicolumn{1}{c}{-} & + \\
\hline None & $100 \pm 20.6^{\mathrm{a}}$ & $10.3 \pm 4.1^{\mathrm{a}, \mathrm{c}}$ \\
BAPTA-AM $(0.5 \mu \mathrm{M})$ & $78.5 \pm 21.3^{\mathrm{b}}$ & $17.1 \pm 3.0^{\mathrm{b}, \mathrm{c}}$ \\
\hline
\end{tabular}

BAPTA-AM: 1,2-bis(2-aminophenoxy)ethane-N,N,N',N'-tetraacetic acid tetraacetoxymethyl ester.

Cell proliferation was determined by 5-bromo-2-deoxyuridine incorporation during DNA synthesis, and results are given as mean \pm standard deviation $(n=6)$. The value for vehicletreated samples was defined as $100 \%$.

a, b, c $P<0.05$ (Tukey's test) between values labeled with the same letter. 
Table 3. Nivalenol induced IL-8 secretion from HL60 cells

\begin{tabular}{cc}
\hline Nivalenol $(\mu \mathrm{g} / \mathrm{ml})$ & IL-8 $(\mathrm{pg} / \mathrm{ml})$ \\
\hline 0 & $33.2 \pm 6.1$ \\
0.1 & $22.0 \pm 5.0^{\mathrm{a}}$ \\
0.3 & $61.2 \pm 4.4^{\mathrm{a}}$ \\
1 & $314.1 \pm 12.9^{\mathrm{a}}$ \\
3 & $130.1 \pm 18.5^{\mathrm{a}}$ \\
10 & $42.1 \pm 2.7$ \\
\hline
\end{tabular}

Results are presented as mean \pm standard deviation $(\mathrm{n}=4)$. ${ }^{\text {a }} P<0.05$ (Dunnett's test) versus value for vehicle-only (i.e., 0 $\mu \mathrm{g} / \mathrm{ml}$ nivalenol) control

treatments was statistically significant $(P<0.05$; Table 2$)$. That BAPTA-AM moderately impaired the cyotoxicity of nivalenol indicates that this effect is partly dependent on intracellular calcium ion. We also tested other calcium modulators, including verapamil (calcium channel blocker), ethylene glycolbis(2-aminoethyl ether)-N,N,N',N'-tetraacetic acid (EGTA; extracellular calcium ion chelator), and K252a (inhibitor of calmodulin kinase II and protein kinase $\mathrm{C}$ ), but they all lacked significant effect on nivalenol-caused inhibition of cell proliferation (data not shown).

The proinflammatory cytokine IL-8 is known to be indispensable to the development of diverse pathologic phenomena; accordingly, we investigated whether nivalenol induces IL-8 secretion from HL60 cells. Whereas treatment with $0.1 \mu \mathrm{g} / \mathrm{ml}$ nivalenol decreased IL-8 secretion slightly, $0.3 \mu \mathrm{g} / \mathrm{ml}$ and higher concentrations increased IL-8 secretion from HL60 cells (Table 3). The values from samples treated with 3 or $10 \mu \mathrm{g} / \mathrm{ml}$ nivalenol were smaller than that from cells exposed to $1 \mu \mathrm{g} / \mathrm{ml}$ nivalenol, probably because of damage to the cells (Fig. 2C, D). Sugita-Konishi and Pestka also found that nivalenol induced IL-8 secretion from U937 cells ${ }^{12)}$, consistent with the possibility that IL-8 is responsible for nivalenol-caused pathologic phenomena.

In the present study, we demonstrated that intracellular calcium ion plays a role in nivalenolcaused cytotoxicity in HL60 cells. We also showed that nivalenol induces IL-8 secretion from HL60 cells. However, further studies are needed to elucidate the detailed mechanism of cytotoxicity and IL8 secretion evoked by nivalenol.

This work was supported by Integrated Research Program for Functionality and Safety of Food toward an Establishment of Healthy Diet from Ministry of Agriculture, Forestry and Fisheries, Japan.

\section{References}

1 ) Sugiura, Y., Fukasaku, K., Tanaka, T., Matsui, Y., Ueno, Y.: Appl. Environ. Microbiol., 59, 3334-3338 (1993)

2 ) Yoshizawa, T., Jin, Y.Z.: Food Addit. Contam., 12, 689-694 (1995)

3 ) Ryu, J.-C., Ohtsubo, K., Izumiyama, N., Nakamura, K., Tanaka, T., Yamamura, H., Ueno, Y.: Fund. Appl. Toxicol., 11, 38-47 (1988)

4 ) Joffe, A.Z.: "Microbial Toxins VII" (eds. Kadis, S., Ciegler, A., Ajl, S.J.) pp.139-189 (1971), Academic Press, Inc., New York, USA

5 ) Nagashima, H., Goto, T.: Toxicol. Lett., 118, 47-51 (2000) 
6 ) Nagashima, H., Nakamura, K., Goto, T.: "Animal Cell Technology: Basic \& Applied Aspects, Volume 12" (eds. Shirahata, S., Teruya, K., Katakura, Y.) pp.455-459 (2002), Kluwer Academic Publishers, Dordrecht, The Netherlands

7 ) Otsubo, K., Yamada, M., Saito, M.: Jpn. J. Med. Sci. Biol., 21, 185-194 (1968)

8 ) Minervini, F., Fornelli, F., Flynn, K.M.: Toxicol. in vitro, 18, $21-28$ (2004)

9 ) Thuvander, A., Wikman, C., Gadhasson, I.: Food Chem. Toxicol., 37, 639-648 (1999)

10) Johannisson, A., Björkhag, B., Hansson, W., Gadhasson, I.-L., Thuvander, A.: Cell Biol. Toxicol., 15, 203$215(2000)$

11) Yang, G.-H., Jarvis, B.B., Chung, Y.J., Pestka, J.J.: Toxicol. Appl. Pharmacol., 164, 149-160 (2000)

12) Sugita-Konishi, Y., Pestka, J.J.: J. Toxicol. Environ. Health A, 64, 619-636 (2001)

13) Ueno, Y., Umemori, K., Niimi, E., Tanuma, S., Nagata, S., Sugamata, M., Ihara, T., Sekijima, M., Kawai, K., Ueno, I., Tashiro, F.: Nat. Toxins, 3, 129-137 (1995)

14) Yoshino, N., Takizawa, M., Akiba, H., Okumura, H., Tashiro, F., Honda, M., Ueno, Y.: Nat. Toxins, 4, 234241 (1996)

\section{HL60 細胞に対するニバレノールの細胞毒性}

長嶋 等, 中川博之, 岩下恵子 : 独立行政法人農業・食品産業技術総合研究機構食品総合研究所 (305-8642 つくば市観音台 2-1-12)

ニバレノールの毒性発現メカニズムを解明するために, ニバレノールで 24 時間処理したヒト白血病細胞 HL60 を用いて細胞毒性試験を行い，インターロイキン- 8 (IL-8) 分泌誘導を調べた $.1 \mu \mathrm{g} / \mathrm{ml}$ ニバレノー ル処理により，形態的にわずかな損傷が観察された .これに対して 3 あるいは $10 \mu \mathrm{g} / \mathrm{ml}$ ニバレノール処理 では , 細胞の損傷は顕著であった . 細胞増殖を具化デオキシウリジン $(\mathrm{BrdU})$ の取り込みで測定した結果， ニバレノールの 50 \%阻害濃度 $\left(\mathrm{IC}_{50}\right)$ は $0.16 \mu \mathrm{g} / \mathrm{ml}$ であった . ニバレノールがミトコンドリアのコハク酸 脱水素酵素に与える影響を water soluble tetrazolium-8 アッセイで調べた結果， $\mathrm{IC}_{50}$ は $0.40 \mu \mathrm{g} / \mathrm{ml}$ であった 。 細胞質の漏出による培養上清の乳酸脱水素酵素活性は, $10 \mu \mathrm{g} / \mathrm{ml}$ ニバレノールにおいても非常に低かった . このことは, $10 \mu \mathrm{g} / \mathrm{ml}$ ニバレノール処理された細胞においては形態的損傷は激しいが, 弚れでも細胞は破 裂していないことを示している.細胞内カルシウムイオンのキレーター1,2-bis(2-aminophenoxy)ethaneN,N,N',N'-tetraacetic acid tetraacetoxymethyl ester (BAPTA-AM) のニバレノールの毒性に対する影響を，最 も鋭敏な細胞毒性試験である BrdU 取り込みを用いて調べた . ニバレノールと BAPTA-AM で同時処理した 時の值は，ニバレノール単独処理に比べて高かった .このことは , ニバレノールの細胞毒性発現に細胞内力 ルシウムイオンが部分的に関与することを示している . ニバレノール処理した細胞の培養上清から IL-8 が 検出された .このことは , IL-8 がニバレノールによる中毒に関与する可能性を示唆するものである .

キーワード : ニバレノール , インターロイキン - 8, BAPTA-AM , HL60 細胞 